\title{
GAMBARAN TINGKAT KEPUASAN PELAYANAN PADA PASIEN BPJS PBI DAN PASIEN BPJS NON PBI YANG DIRAWAT DI KELAS III RUMAH SAKIT PKU MUHAMMADIYAH GOMBONG
}

\author{
Siti Mastuti ${ }^{*}$, Febriana Nurul DAM, Kusumastuti \\ Universitas Muhammadiyah Gombong \\ E-Mail: mastutis5758@gmail.com
}

\begin{abstract}
Abstrak
Kata Kunci : Latar Belakang : Kepuasan pasien merupakan hal utama yang diperhatikan tingkat kepuasan, dalam melakukan pelayanan. Keberhasilan layanan yang disediakan di fasilitas pelayanan kesehatan adalah tingkat kepuasan pasien. Kementerian Kesehatan Republik Indonesia berpendapat bahwa Badan Penyelenggara Jaminan Sosial (BPJS) adalah badan hukum publik yang diciptakan guna melaksanakan program jaminan sosial. Peserta BPJS Kesehatan terbagi menjadi dua yang pertama adalah masyarakat tidak mampu yang menerima bantuan iuran (PBI) dan yang kedua peserta Non PBI yang merupakan peserta penerima upah (PPU), peserta bukan penerima upah (PBPU) dan bukan pekerja yang biayanya ditanggung sendiri ataupun kolektif ke BPJS Kesehatan.

Tujuan : Mengetahui gambaran tingkat kepuasan pelayanan pada pasien BPJS PBI dan pasien BPJS Non PBI yang dirawat di kelas III Rumah Sakit PKU Muhammadiyah Gombong.

Metode Penelitian : Penelitian ini menggunakan rancangan penelitian deskriptif kuantitatif dengan pendekatan cross sectional. Populasi dalam penelitian ini adalah BPJS PBI 767 pasien dan BPJS Non PBI 106 pasien. Pengambilan sampel menggunakan probability sampling sebanyak BPJS PBI 20 pasien dan BPJS Non PBI 10 pasien. Data dianalisis secara univariat.

Hasil : Penelitian ini menunjukkan hasil pada karakteristik pasien BPJS PBI jenis kelamin paling banyak yaitu perempuan 16 orang (80\%), tingkat pendidikan mayoritas SMA 8 orang (40\%) dan BPJS Non PBI pada jenis kelamin yang paling banyak adalah laki-laki 6 orang (60\%), tingkat pendidikan paling banyak SMP 5 orang (50\%). Hasil pada pasien BPJS PBI menunjukkan 11 orang $(55 \%)$ dari 20 responden memilih kategori puas dan pasien BPJS Non PBI menunjukkan hasil 9 orang (90\%) dari 10 responden memilih kategori sangat puas.

Rekomendasi : Hasil penelitian ini diharapkan menjadi acuan atau referensi dalam mengatasi permasalahan yang ada dan meningkatkan kualitas dalam hal pelayanan dan sebagai tambahan pengetahuan tentang pemanfaatan pelayanan kesehatan di Rumah Sakit.
\end{abstract}

\section{PENDAHULUAN}

Kesehatan sebagai bagian penting dalam pembangunan nasional, bertujuan untuk menciptakan pola hidup masyarakat yang peduli, mengerti, dan tanggap akan permasalahan kesehatan yang ada di lingkungan. Dengan demikian diperlukan peningkatan kualitas dan kuantitas pelayanan kesehatan yang ada dari lembaga kesehatan.
Keperawatan merupakan suatu bentuk pelayanan profesional yang menjadi bagian integral dari layanan kesehatan berbasis ilmu dan kiat keperawatan, yang berbentuk layanan komprehensif yang ditujukan bagi individu, keluarga, kelompok, dan masyarakat baik sehat maupun sakit, yang mencakup keseluruhan proses kehidupan manusia. Pelayanan merupakan suatu kewajiban yang harus di lakukan dengan baik oleh pemberi jasa agar 
memuaskan kebutuhan dan keinginan pasien (Asmadi, 2005 dalam Hidayat, 2012).

Kepuasan pasien merupakan hal utama yang harus diperhatikan dalam melaksanakan pelayanan. Tolok ukur dalam keberhasilan layanan yang disediakan di fasilitas kesehatan adalah tingkat kepuasan pasien. Tingkat kepuasan pasien terhadap pelayanan merupakan faktor penting dalam mengembangkan sistem penyediaan pelayanan yang tanggap terhadap kebutuhan pasien, meminimalkan biaya dan waktu serta memaksimalkan dampak pelayanan terhadap populasi sasaran, kepuasan dalam menerima pelayanan dapat diraih jika pasien atau pelanggan mendapatkan pelayanan menurut apa yang diperlukan dan diinginkan (Singh et al, 2013).

Organisasi Kesehatan Dunia memberikan dorongan kepada semua negara untuk memberikan serta mengembangkan jaminan kesehatan kepada semua penduduknya (Universal Health Coverage). Dengan begitu jaminan kesehatan masyarakatnya tidak perlu khawatir dengan biaya yang dibayar selama menerima pelayanan kesehatan yang memuaskan dan optimal (WHO, 2015). Kementerian Kesehatan Republik Indonesia berpendapat bahwa Badan Penyelenggara Jaminan Sosial (BPJS) merupakan badan hukum publik yang diciptakan guna melaksanakan program jaminan sosial. BPJS ini meliputi BPJS Ketenagakerjaan dan BPJS Kesehatan. BPJS Kesehatan merupakan badan hukum yang diciptakan guna melaksanakan program jaminan kesehatan. Pelaksanaan BPJS Kesehatan mulai beroperasi pada tanggal 1 Januari 2014 (Kementerian Kesehatan RI, 2013).

Peserta BPJS kesehatan terbagi dua yang pertama adalah masyarakat tidak mampu yang biayanya akan ditanggung oleh pemerintah disebut dengan peserta Penerima Bantuan Iuran (PBI) dan kedua adalah peserta Non PBI terdiri dari Peserta Penerima Upah (PPU), Peserta Bukan Penerima Upah (PBPU) dan Bukan Pekerja yang biayanya ditanggung sendiri ataupun kolektif ke BPJS Kesehatan. Awal pelaksanaan program JKN banyak mengalami beberapa kendala antara lain yaitu penduduk masih ada yang belum terdaftar sebagai peserta, distribusi pelayanan kesehatan masih belum merata, kualitas pelayanan kesehatan yang bervariasi, serta pelayanan kesehatan masih belum optimal (Peraturan BPJS Kesehatan, 2014).

Masyarakat perlu memahami bahwa tujuan jaminan kesehatan yaitu untuk mempermudah masyarakat untuk mengakses pelayanan kesehatan yang bermutu dan sesuai dengan prosedur. (BPJS, 2015). Banyak ditemukan keluhan dipelayanan rawat inap terutama pada pasien yang dirawat menggunakan fasilitas sebagai peserta BPJS kesehatan. Diantara keluhan-keluhan tersebut antara lain adalah tidak puas terhadap pelayanan kesehatan yang diberikan, kurangnya informasi tentang pelayanan yang ada, kurangnya komunikasi pada saat pemberian pelayanan, merasa dibedakan dengan pasien yang lain. Sesuai prinsip dan asas etik keperawatan yaitu asas keadilan "justice", pasien dan keluarganya seharusnya diperlakukan sama sesuai dengan keadaan sakitnya dan tidak ada diskriminasi (Nursalam, 2014).

Berdasarkan hasil penelitian Wahyu Kuntoro dan Wahyudi Istiono (2017) mengatakan bahwa pasien $84 \%$ menyatakan puas terhadap pelayanan perawat dan hasil penelitian dari Gurendro Putro dan Iram Barida (2016) juga berpendapat bahwa sebanyak $71,3 \%$ yang mengetahui tentang BPJS Kesehatan dan sebanyak 9,6\% yang menjadi peserta BPJS dan didapatkan data dari Badan Penyelenggaraan Jaminan Kesehatan diseluruh Indonesia pada tahun 2019 jumlah peserta yang menggunakan BPJS mencapai 224,1 juta atau $83 \%$ dari jumlah data tersebut di bagi menjadi dua golongan yang pertama BPJS PBI yang berjumlah 96,5 juta di antaranya merupakan peserta penerima bantuan iuran (PBI) Anggaran Penerimaan dan Belanja Negara (APBN) dan 38,8 juta lainnya peserta PBI Anggaran Penerimaan dan Belanja Daerah (APBD). Kemudian yang kedua BPJS Non PBI yang berjumlah 14,7 juta peserta merupakan pekerja penerima upah (PPU) Pegawai Negeri 
Sipil (PNS). Sebanyak 1,57 juta PPU TNI, 1,28 juta PPU Polri, dan 1,57 juta PPU Badan Usaha Milik Negara (BUMN) (BPJS, 2019).

Dari studi pendahuluan pasien BPJS PBI dan pasien BPJS Non PBI yang dirawat dikelas III Rumah Sakit PKU Muhammadiyah Gombong dalam waktu bulan Desember tahun 2019 dan Januari tahun 2020 pasien BPJS PBI berjumlah 767 orang dan pasien BPJS Non PBI berjumlah 106 orang. Dari hasil wawancara yang saya lakukan dengan 10 orang terdiri dari 5 orang pasien BPJS PBI dan 5 orang pasien BPJS Non PBI yang dirawat dikelas III, ada 7 orang yang mengatakan puas dengan pelayanan perawat yang diberikan dan ada 3 yang mengatakan belum merasa puas dengan pelayanan perawat yang diberikan diruang rawat kelas III.

Tujuan penelitian ini yaitu untuk mengetahui gambaran tingkat kepuasan pelayanan pada pasien BPJS PBI dan Non PBI yang dirawat di kelas III Rumah Sakit PKU Muhammadiyah Gombong.

\section{METODE}

Penelitian ini menggunakan rancangan penelitian deskriptif kuantitatif. Populasi dalam penelitian ini adalah semua pasien BPJS PBI dan pasien BPJS Non PBI yang dirawat di kelas III Rumah Sakit PKU Muhammadiyah Gombong dalam waktu bulan Desember dan Januari sebanyak pasien BPJS PBI berjumlah 767 orang dan pasien BPJS Non PBI berjumlah 106 orang. 30 pasien pengambilan sampel dilakukan dengan cara probability sampling. Instrument atau alat ukur yang menggunakan kuesioner. Data dianalisis secara univariat.

\section{HASIL PENELITIAN}

\section{Jenis Kelamin Pasien BPJS PBI}

\begin{tabular}{clll}
\hline No & Jenis Kelamin & Jumlah & Persentase \\
\hline 1 & Laki - laki & 4 & $20 \%$ \\
2 & Perempuan & 16 & $80 \%$ \\
\hline \multicolumn{2}{c}{ Total } & 20 & $100 \%$
\end{tabular}

Berdasarkan tabel dalam penelitian ini terdapat responden berjenis laki-laki sebanyak 4 orang (20\%) dan perempuan 16 orang $(80 \%)$.
Tingkat Pendidikan Pasien BPJS PBI

\begin{tabular}{cccc}
\hline No & Pendidikan & Jumlah & Persentase \\
\hline 1 & SD & 5 & $25 \%$ \\
2 & SMP & 5 & $25 \%$ \\
3 & SMA & 8 & $40 \%$ \\
4 & Perguruan & 2 & $10 \%$ \\
& Tinggi & & \\
\hline & Total & 20 & $100 \%$
\end{tabular}

Berdasarkan terdapat empat tingkat pendidikan pada responden yaitu SD sebanyak 5 orang (25\%), SMP ada 5 orang (25\%), SMA sebanyak 8 orang (40\%), SMA merupakan persentase tertinggi, dan Perguruan Tinggi 2 orang (10\%) adalah persentase paling sedikit dari pada yang lainnya.

\section{Jenis Kelamin Pasien BPJS Non PBI}

\begin{tabular}{llll}
\hline No & Jenis Kelamin & Jumlah & Persentase \\
\hline 1 & Laki - laki & 6 & $60 \%$ \\
2 & Perempuan & 4 & $40 \%$ \\
\hline & Total & 10 & $100 \%$
\end{tabular}

Berdasarkan table diatas responden pada penelitian ini terdapat jenis kelamin laki laki yang mempunyai persentase lebih banyak yaitu 6 orang $(60 \%)$ dari perempuan yang berjumlah lebih sedikit yaitu 4 orang (40\%).

\section{Tingkat Pendidikan Pasien BPJS Non PBI}

\begin{tabular}{llll}
\hline No & Pendidikan & Jumlah & Persentase \\
\hline 1 & SD & 3 & $30 \%$ \\
2 & SMP & 5 & $50 \%$ \\
3 & SMA & 1 & $10 \%$ \\
4 & Perguruan Tinggi & 1 & $10 \%$ \\
\hline & Total & 10 & $100 \%$
\end{tabular}

Berdasarkan tabel pada penelitian ini terdapat tingkat pendidikan pada responden yang terdiri dari empat yaitu SD sebanyak 3 orang (30\%), SMP sebanyak 5 orang (50\%), SMA 1 orang (10\%), dan Perguruan Tinggi 1 orang (10\%).

\section{Kepuasan Pelayanan Pasien BPJS PBI}

\begin{tabular}{lll}
\hline Kepuasan & Frekuensi & Persentase \\
\hline Sangat Tidak Puas & 0 & $0 \%$ \\
Tidak Puas & 0 & $0 \%$ \\
Puas & 11 & $55 \%$ \\
Sangat Puas & 9 & $45 \%$ \\
\hline Total & 20 & $100 \%$ \\
\hline
\end{tabular}


Berdasarkan tabel dapat diketahui bahwa responden dengan tingkat kepuasan pelayanan pasien puas sejumlah 11 responden (55\%), sedangkan responden dengan tingkat kepuasan pelayanan pasien sangat puas sejumlah 9 responden $(45 \%)$.

\section{Kepuasan Pelayanan BPJS Non PBI}

\begin{tabular}{lll}
\hline Kepuasan & Frekuensi & Persentase \\
\hline Sangat Tidak Puas & 0 & $0 \%$ \\
Tidak Puas & 0 & $0 \%$ \\
Puas & 1 & $10 \%$ \\
Sangat Puas & 9 & $90 \%$ \\
\hline Total & 10 & $100 \%$ \\
\hline
\end{tabular}

Berdasarkan tabel dapat diketahui bahwa tingkat kepuasan pelayanan dengan kategori puas berjumlah 1 orang (10\%), sedangkan tingkat kepuasan pelayanan dengan kategori sangat puas berjumlah 9 orang $(90 \%)$.

\section{PEMBAHASAN}

\section{Karakteristik Responden}

Hasil penelitian menunjukkan bahwa jenis kelamin pasien BPJS PBI pada 20 responden didapatkan perempuan 16 orang $(80 \%)$ dan laki-laki 4 orang (20\%). Dari data hasil tabulasi jenis kelamin pada pasien BPS PBI perempuan lebih banyak yang dirawat di kelas III dari pada jenis kelamin laki-laki hal ini terjadi karena pada umumnya perempuan lebih rentan terhadap penyakit dan lebih banyak menginginkan untuk mendapat bantuan kesehatan jika mengalami masalah kesehatan dibandingkan dengan laki-laki.

Wanita pada umumnya lebih banyak melaporkan gejala sakit dibandingkan dengan laki-laki (Pennebaker (1982) dalam Rahmawati (2017)). Menurut Nursalam (2011) Jenis kelamin merupakan suatu sifat yang melekat pada kaum perempuan maupun laki-laki yang dikontruksikan secara sosial maupun kultural. Menurut Gunarsa (2017) juga berpendapat bahwa jenis kelamin memiliki pengaruh pada pandangan terhadap jasa yang diberikan terutama pada perempuan lebih banyak melihat penampilan secara detail, sementara laki-laki tidak mengindahkan hal tersebut.
Berdasarkan penelitian yang dilakukan oleh Sarah (2017), menyatakan bahwa pasien dengan jenis kelamin perempuan $(61,6 \%$ sebanyak 64 orang dan laki-laki $(38,5 \%)$ sebanyak 40 orang hal ini terjadi karena jumlah penduduk wanita lebih banyak dari pada pria, yaitu mencapai $(51,7 \%)$. Hasil penelitian ini sejalan dengan penelitian-penelitian yang telah dilakukan sebelumnya seperti penelitian yang dilakukan oleh Suryati (2017) menyatakan hasil dari 120 sampel yang dirawat di kelas III paling banyak adalah perempuan sebanyak $(63,3 \%)$.

Hasil penelitian menunjukkan tingkat pendidikan pada pasien BPJS PBI dari 20 responden yaitu SMA 8 orang (40\%), SMP 5 orang (25\%), SD 5 orang (25\%), Perguruan Tinggi 2 orang (10\%). Pendidikan terakhir responden paling banyak adalah SMA.

Pendidikan jenjang SMA akan mempunyai kemampuan lebih baik menerima pesan yang disampaikan sehingga mereka lebih tahu tentang haknya dan aktif bertanya karena lebih kritis dan ingin tahu tentang sakit yang dideritanya, terkadang karena kecanggihan teknologi pasien mencari kebenaran yang telah dijelaskan petugas kesehatan melalui handphone dan media yang dimiliki.

Menurut Irine (2015), pembelajaran didalam pendidikan meliputi perubahan perilaku seseorang yang timbul dari pengalaman sebagian besar perilaku manusia adalah hasil dari belajar ahli teori pembelajaran yakin bahwa pembelajaran dihasilkan melalui perpaduan kerja antara dorongan, rangsangan, petunjuk, tanggapan, dan penguatan. Pendidikan merupakan proses pengajaran baik formal maupun informal.

Berdasarkan penelitian yang dilakukan oleh Sintia (2018) menyatakan bahwa tingkat Pendidikan terbanyak adalah SMA dengan 52 $(54,2 \%)$ responden semakin tinggi tingkat Pendidikan pasien, maka semakin tinggi pula harapannya terhadap suatu pelayanan yang dapat memberikan kepuasan.

Hasil penelitian menunjukkan bahwa jenis kelamin pada pasien BPJS Non PBI pada 10 responden didapatkan laki-laki 6 orang $(60 \%)$ dan perempuan 4 orang (40\%). Dari tabulasi 
jenis kelamin pada pasien BPJS Non PBI lakilaki lebih banyak daripada perempuan ini terjadi karena pasien laki-laki cenderung lebih bisa menerima dan menilai pelayanan yang didapatkan dibandingkan dengan perempuan yang lebih kritis dalam menilai pelayanan yang diberikan oleh perawat. Laki-laki cenderung lebih berdiam diri dan menutupi perasaannya, sehingga laki-laki mudah untuk mengatakan puas terhadap pelayanan yang didapatkan selama dirawat.

Menurut penelitian yang dilakukan oleh Ajeng (2012), Jenis kelamin laki-laki cenderung merasa puas dikarenakan laki laki menilai secara terus terang, apa adanya, dan lebih sabar serta mengikuti alur prosedur yang ada, jenis kelamin laki-laki tidak menuntut terlalu banyak dan lebih menerima pelayanan apa adanya sehingga tingkat kepuasan laki-laki lebih tinggi terhadap pelayanan yang diberikan oleh perawat.

\section{Tingkat Pendidikan}

Hasil penelitian menunjukkan bahwa tingkat pendidikan pasien BPJS Non PBI dari 10 responden yaitu SD 3orang (30\%), SMP 5 orang (50\%), SMA 1 orang (10\%), Perguruan Tinggi 1 orang (10\%). Tingkat pendidikan paling banyak pada pasien BPJS Non PBI adalah SMP 5 orang (50\%). Berdasarkan data diatas dapat dilihat bahwa tingkat pendidikan pasien tidak mempengaruhi pemahaman terhadap pelayanan yang diberikan oleh perawat yang dapat meningkatkan kepuasan.

Pasien dengan tingkat pendidikan yang rendah menyebabkan pengetahuan yang rendah pula tentang pentingnya kesehatan sehingga mereka kurang memahami manfaat pelayanan kesehatan. Tingkat pendidikan terkait dengan kemampuan seseorang menyerap informasi serta mengenali gejala penyakit sehingga memiliki keinginan untuk memanfaatkan pelayanan kesehatan dan aktif berperan mengatasi masalah kesehatannya.

Pendidikan yang rendah ataupun tinggi tidak menjamin seseorang merasakan kepuasan pada pelayanan yang diberikan oleh perawat. Tingkat pendidikan seseorang mempengaruhi cara pola pikir yang akan menentukan atau mempengaruhi tindakan yang akan dilakukan terutama mengenai informasi terkait pelayanan yang dapat meningkatkan kepuasan pada saat dirawat dirumah sakit (Sunarsih, 2016). Status pendidikan seseorang juga bisa mempengaruhi bagaimana cara memperoleh informasi mengenai penatalaksanaan pada pelayanan (Notoatmodjo, 2012).

Berdasarkan penelitian yang dilakukan oleh Agustina (2016) berpendapat bahwa seseorang yang memiliki pendidikan yang tinggi akan mempunyai pengetahuan yang lebih luas dan memungkinkan dapat mengontrol dirinya dalam mengatasi masalah, mempunyai rasa percaya diri yang tinggi, berpengalaman, mudah mengerti tentang apa yang dianjurkan oleh petugas kesehatan, serta dapat mengurangi kecemasan sehingga membantu individu tersebut membuat keputusan. Semakin tingginya pendidikan yang dimiliki oleh pasien maka semakin tinggi pula harapan pasien tersebut terhadap pelayanan kesehatan, sedangkan pasien dengan tingkat pendidikan yang rendah mungkin lebih mengapresiasi segala bentuk pelayanan yang didapatkan.

\section{Kepuasan Pasien BPJS PBI}

Hasil penelitian menunjukan bahwa pasien BPJS PBI yang mengatakan puas (55\%) sebanyak 11 orang dan sangat puas $(45 \%)$ sebanyak 9 orang dari 20 sampel. Dari data diatas didapatkan hasil bahwa pelayanan yang mempengaruhi kepuasan pasien yang diberikan oleh perawat dikelas III masih harus ditingkatkan dalam memenuhi harapan pasien seperti dalam hal tepat waktu pada saat melakukan tindakan, tekun dalam melakukan tugasnya, memberikan tanggapan yang baik dan cepat terhadap keluhan pasien dan selalu menunjukkan sikap profesional dalam setiap melakukan tugasnya.

Kepuasan pelayanan merupakan perasaan senang maupun perasaan yang puas seorang individu karena terpenuhnya sebuah harapan ataupun keinginan dalam menerima jasa dalam peyanan kesehatan yang diberikan (Purwanto, 2012). Kepuasan biasa terjadi setelah seseorang 
membandingkan sebuah kinerja maupun hasil yang dirasakan dengan harapan yang diinginkan (Supranto, 2015). Pasien merasa puas apabila harapannya terpenuhi atau akan sangat puas apabila harapannya terlampaui.

Berdasarkan penelitian yang dilakukan oleh Bilal (2017) menyatakan $74 \%$ responden puas terhadap pelayanan rawat inap di Rumah Sakit Panti Wilasa Citarum Semarang dan sebesar $26 \%$ tidak puas hal ini menunjukkan bahwa kemudahan persyaratan teknis maupun administratif untuk memperoleh pelayanan yang sesuai dengan jenis pelayanan dianggap penting oleh konsumen sehingga tercipta kepuasan pasien. Hasil penelitian ini juga sejalan dengan penelitian-penelitian yang telah dilakukan sebelumnya seperti yang dilakukan oleh Murtiana (2016) menunjukkan hampir seluruh responden dari kelompok BPJS termasuk puas hal ini mengacu kepada teori yang ada bahwa kepuasan akan terwujud jika pasien mendapatkan pelayanan sesuai atau melebihi dari keinginan atau harapannya.

\section{Kepuasan Pasien BPJS Non PBI}

Berdasarkan hasil penelitian menunjukkan bahwa pasien BPJS Non PBI yang mengatakan sangat puas (90\%) sebanyak 9 orang dan puas (10\%) sebanyak 1 orang dari total sampel 10 orang. Dari data diatas bahwa pelayanan yang diberikan oleh perawat sesuai dengan apa yang pasien harapkan seperti hal ramah dalam memberikan pelayanan, selalu tersenyum pada saat komunikasi, tidak membeda-bedakan setiap pasien yang dilayani perawat pada saat melakukan tindakan.

Tingkat kepuasan pelayanan didefinisikan sebagai respon pasien terhadap ketidak sesuaian antara tingkat kepentingan sebelumnya dan kinerja aktual yang dirasakannya setelah pemakaian (wahyu \& wahyudi, 2017). Kepuasan pasien adalah inti dari pemasaran yang berorientasi kepada pasien. Pelayanan yang memuaskan dan berkualitas akan membentuk loyalitas pasien, dan kepuasan sangat erat hubungannya dengan pelayanan maka pelayanan yang memuaskan tersebut juga akan mendatangkan pasien baru. Efek selanjutnya akan berlanjut pada proses terbentuknya citra rumah sakit yang meningkat.

\section{KESIMPULAN DAN SARAN}

a. Hasil karakteristik pada penelitian pasien BPJS PBI pada jenis kelamin adalah perempuan 16 orang (80\%), tingkat pendidikan paling banyak yaitu SMA 8 orang (40\%) dan pasien BPJS Non PBI jenis kelamin paling banyak laki-laki 6 orang $(60 \%)$, tingkat pendidikan mayoritas adalah SMP 5 orang (50\%).

b. Tingkat kepuasan pelayanan pasien BPJS PBI yang dirawat di kelas III Rumah Sakit PKU Muhammadiyah Gombong menunjukkan sebanyak 11 orang (55\%) dari 20 responden yang memilih kategori puas.

c. Tingkat kepuasan pelayanan pada pasien BPJS Non PBI yang dirawat di kelas III Rumah Sakit PKU Muhammadiyah Gombong pada penelitian ini menunjukkan 9 orang $(90 \%)$ dari 10 responden memilih kategori sangat puas dengan pelayanan perawat yang diberikan.

Menjadi acuan atau referensi untuk penelitian selanjutnya tentang determinan yang mempengaruhi tingkat kepuasan pelayanan pasien umum yang dirawat di kelas III.

\section{REFERENSI}

[1] Andika, F, \& Astuti, A. (2018). Analisis Faktor Kepuasan Pasien BPJS JKRA Dengan Kinerja Perawat Di Rawat Inap Rumah Sakit Umum Daerah Meuraxa Kota Banda Aceh. Jurnal Teknologi Kesehatan dan Kedokteran Vol. 4 No. 2. Banda Aceh: Program Studi Ilmu Kesehatan Masyarakat, Universitas Ubudiyah Indonesia

[2] Fitriyanah, E. aini, N, I. Utomo, P, T. (2017). Perbedaan Tingkat Kepuasan Pasien Bpjs Dan Pasien Umum Tentang Mutu Pelayanan Keperawatan Unit Rawat Inap Kelas 3 Rsud Dr. H Soewondo Kendal. Semarang: STIKES Telogorejo Semarang. 
[3] Hidayat, A. (2012). Pengantar Kebutuhan Dasar Manusia: Aplikasi Konsep dan Proses Keperawatan. Jakarta: Salemba Medika V.

[4] Istiono, W \& Kuntoro, W. (2017). Kepuasan Pasien Terhadap Kualitas Pelayanan di Tempat Pendaftaran Pasien Rawat Jalan Puskesmas Kretek Bantul Yogyakarta. Jurnal Kesehatan Vokasional Vol. 2 No 1. Yogyakarta: Universitas Gajah Mada.

[5] Kementerian Kesehatan R.I. (2013). BPJS Kesehatan. Jakarta: Kementerian Kesehatan.

[6] Notoatmodjo, S. (2012). Metodologi Penelitian Kesehatan. Jakarta: Rineka Medika.

[7] Nursalam. (2011). Manajemen Keperawatan.edisi 3. Jakarta: Salemba Medika.

[8] Nursalam. ((2014). Manajemen Keperawatan: Aplikasi dalam Praktik Keperawatan Profesional Edisi 4. Jakarta: Salemba Medika.

[9] Pertiwi, N, A, A. (2016). Analisis Perbedaan Kualitas Pelayanan Pada Pasien Bpjs Dan Pasien Umum Terhadap Kepuasan Pasien Di Rawat Jalan Rsud Kota Surakarta. Jurnal
Ekonomi Manajemen Sumber Daya Vol. 18, No. 2. Surakarta: Program Studi Magister Manajemen, Universitas Muhammadiyah Surakarta.

[10] Purwanto. (2012). Kepuasan Pasien terhadap Pelayanan Rumah Sakit. https://klinis.wordpress.com. (Diakses pada 01 Februari 2020).

[11] Putro, G \& Barid, I. (2016). Manajemen Peningkatan Kepesertaan dalam Jaminan Kesehatan Nasional pada Kelompok Nelayan Non Penerima Bantuan Iuran (Non PBI). Jakarta: Media Litbangkes.

[12] Putrol, G \& Barida, I. (2017). Manajemen Peningkatan Kepesertaan dalam Jaminan Kesehatan Nasional pada Kelompok Nelayan Non Penerima Bantuan Iuran (Non PBI). Vol. 27 No. 1. Jakarta: Media Litbangkes.

[13] Singh, S. Kaur, P. Rochwani, R. (2013). Patient satisfaction levels in a tertiary care medical college hospital in Punjab, North India. International Journal of

[14] World Health Organization. (2015). Universal Health Coverage. http://www.who.int/mediacentre/factshee ts/fs395/en/. (Diakses pada 02 Februari 2020). 